\title{
Variabel Anteseden Komitmen Sumber Daya Manusia Sektor Publik Berbasis Spirituality
}

\author{
I Made Purba Astakoni ${ }^{1 *}$, I Wayan Wardita ${ }^{2}$, Ni Made Gunastri ${ }^{3}$, Ni Made Satya Utami ${ }^{4}$ dan I Nyoman \\ Mustika $^{5}$ \\ ${ }^{1,2,3}$ Dosen Prodi Manajemen Sekolah Tinggi Ilmu Manajemen Handayani Denpasar \\ 4,5 Dosen Prodi Manajemen Fakultas Ekonomi dan Bisnis Universitas Mahasaraswati Denpasar \\ *astakonimade@gmail.com
}

\section{How to cite (in APA style):}

Astakoni, I. M. P., Wardita, I. W., Gunastri, N. M., Utami, N. M. S., \& Mustika, I. N. (2021). Variabel Anteseden Komitmen Sumber Daya Manusia Sektor Publik Berbasis Spirituality . Wacana Ekonomi (Jurnal Ekonomi, Bisnis dan Akuntansi). 20 (1), pp.55-71. https://doi.org/10.22225/we.20.1.3152.55-71

\begin{abstract}
This study has several purposes namely; analyze the influence of spiritual leadership on workplace spirituality; analyze the influence of spiritual leadership on spiritual survival; analyze the influence of workplace spirituality on an individual spirituality; analyze the influence of spiritual survival on the individual spirituality; analyze an individual spirituality influence on human resource commitments; analyze the role of workplace spirituality and individual spirituality as mediating on the influence of spiritual leadership on human resource commitments and analyze the role of spiritual survival and individual spirituality as mediating on the spiritual influence of leadership on human resource commitments. This study used the population of all employees of drinking water companies in Denpasar, Badung and Tabanan districts as many as 902 employees. The sample number of 200 respondents was done purfosively. Closed multiple-choice questionnaire tools are used for Data collection techniques, and data analysis using the Partial Least Square (PLS) approach. The results showed that the overall evaluation of the model was seen from the side of $R-S q u a r e(R 2)$, $Q$-Square Predictive Relevance (Q2) and Goodness of Fit (GoF) then the model was declared good. Of all the hypotheses raised in the model stated all tested significantly and positively.
\end{abstract}

Keywords: Spiritual Leadership; Spiritual Workplace; Spiritual Survival; Individual Sprituality; Human Resource Commitment

\begin{abstract}
Abstrak
Studi ini memiliki beberapa tujuan yaitu; menganalisis pengaruh spiritual leadership terhadap workplace spirituality; menganalisis pengaruh spiritual leadership terhadap spiritual survival; menganalisis pengaruh workplace spirituality terhadap individual spirituality; menganalisis pengaruh spiritual survival terhadap individual spirituality; menganalisis pengaruh individual spirituality terhadap komitmen sumber daya manusia; menganalisis peran workplace spirituality dan individual spirituality sebagai pemediasi pada pengaruh spiritual leadership terhadap komitmen sumber daya manusia dan menganalisis peran spiritual survival dan individual spirituality sebagai pemediasi pada pengaruh spiritual leadership terhadap komitmen sumber daya manusia. Penelitian ini menggunakan populasi seluruh karyawan perusahaan daerah air minum kota Denpasar, kabupaten Badung dan kabupaten Tabanan sebanyak 902 karyawan. Jumlah sampel sebesar 200 orang responden dilakukan secara purfosive. Alat bantu kuisioner dengan pilihan ganda tertutup digunakan untuk Teknik pengumpulan data, dan analisis data menggunakan pendekatan Partial Least Squre (PLS). Hasil penelitian menunjukkan bahwa evaluasi model secara keseluruhan dilihat dari sisi R-Square (R2), Q-Square Predictive Relevance (Q2) dan Goodness of Fit (GoF) maka model dinyatakan baik. Dari seluruh hipotesis yang diangkat dalam model dinyatakan semua teruji secara signifikan dan positif.
\end{abstract}

Kata Kunci: Spiritual Leadership; Spiritual Workplace; Spiritual Survival; Individual Sprituality; Komitmen Sumber Daya Manusia

\section{PENDAHULUAN}

Pada era saat ini manusia hidup di zaman yang belum pernah terjadi sebelumnya, dimana dunia berubah dengan sangat cepat. Para ilmuwan, peneliti dan dunia akademis percaya bahwa ini adalah masa evolusi manusia yang cepat dalam perkembangan spiritual. Bagi manusia modern tempat kerja 
bukan hanya tempat di mana orang-orang bekerja, tetapi tempat dimana mereka menjalin persahabatan, bersosialisasi, dan berusaha menemukan kepuasan batin. Dalam hal ini bisa juga dimaknai merupakan tempat di mana orang berusaha memahami dan memperoleh makna dari kegiatan yang sering disebut "bekerja" dan bagaimana kegiatan ini cocok dengan jalinan kehidupan individu yang lebih luas (Mansor, Ismail, Mohd. Alwi, \& Anwar, 2013). Jadi spiritualitas adalah suatu keadaan atau pengalaman yang dapat memberikan arah atau makna bagi individu atau memberikan perasaan memahami, semangat, keutuhan dalam diri atau perasaan terhubung. Spiritualitas adalah sebuah proses dalam kehidupan individu, berupa makna dan tujuan, dan semuanya berdampak pada individu lain dan lingkungannya, termasuk organisasi (Hakim \& Azlimin, 2015). Pencarian makna ini telah mendorong adanya pengakuan bahwa kepemimpinan spiritual dan spiritualitas di tempat kerja adalah suatu realitas yang mempengaruhi kualitas hidup serta mengarah pada komitmen dalam organisasi modern. Menurut (Fry, Hannah, Noel, \& Walumbwa, 2011) Spiritual leadership memanfaatkan kebutuhan mendasar dari pemimpin dan pengikut untuk kelangsungan hidup spiritual sehingga mereka menjadi lebih berkomitmen dan produktif secara organisasi. Secara umum Spiritual leadership melibatkan penerapan nilai-nilai dan prinsip-prinsip spiritual ke tempat kerja. Seorang Spiritual leadership memahami pentingnya karyawan menemukan makna dalam pekerjaan mereka dan menunjukkan kepedulian yang tulus terhadap orang secara utuh. Spiritual leadership juga mengupayakan tempat kerja yang benar-benar sebuah komunitas, yang terdiri dari orang-orang dengan tradisi, nilai, dan kepercayaan yang sama.

Kehidupan organisasi mengalami berbagai macam tantangan dalam menjalankan peran dalam mencapai tujuan. Tantangan yang muncul dapat berasal dari dalam maupun luar organisasi. Organisasi yang mampu menghadapi tantangan-tantangan tersebut akan berkembang dan bertahan (Yogatama \& Widyarini, 2015). Dalam organisasi masyarakat modern sering dijumpai karyawan mengalami berbagai tekanan dan kecemasan dalam bekerja. Karyawan sering mengalami keterasingan antar individu dan kelelahan di tempat kerja (Yogatama dan Widyarini 2015). Fry et al. (2017) mengungkapkan bahwa perusahaan ataupun organisasi tidak dapat berkembang dalam norma kerja yang penuh tekanan dan pada sisi lain menuntut karyawannya bekerja secara terus menerus demi keuntungan perusahaan. Eksistensi perusahaan sering mengabaikan hak-hak dan kebutuhan karyawan. Perusahaan membutuhkan norma kerja dengan spiritualitas untuk mendorong peningkatan sikap kerja karyawannya.

Komitmen sumber daya manusia yang kuat merupakan salah satu factor penentu kinerja organisasi (Utami dan Astakoni 2020). Ada beberapa factor yang bisa ditempatkan sebagai anteseden komitmen seperti spiritual leadership, spirituality survival maupun individual spirituality dan workplace spiritual.

Spiritualitas dibutuhkan karena dapat berdampak pada individu, lingkungan, maupun organisasi (Ke, Zhang, Yan, \& Fu, 2017). Memahami spiritualitas berarti menyadari bahwa manusia merupakan makhluk yang memiliki jiwa dan dapat dipengaruhi oleh pekerjaannya (Ashmos dan Duchon 2000a). Terdapat banyak faktor penyebab spiritualitas menjadi topik yang menarik untuk dikaji. Nilai-nilai spiritual di tempat kerja semakin didiskusikan dan diaplikasikan dalam literatur etika bisnis yang dapat dilihat dari sudut pandang individu, kelompok, organisasi, atau interaktif antar yang satu dengan yang lainnya (Milliman, J, Czaplewski, \& Ferguson, 2003). Hal ini terjadi karena organisasi secara perlahan berkembang dari kegiatan ekonomi dan sosial murni ke arena pembangunan spiritual (Fry et al. 2017). Topik mengenai spiritualitas dalam bisnis semakin penting, menarik, dan sudah banyak mewarnai berbagai konferensi, artikel, buku, media-media publikasi, seperti Business Week, Fortune, USA Today, Wall Street Journal, situs online, dan lain sebagainya (Ke et al., 2017). Spiritualitas dalam bisnis yang bermunculan saat ini, setengahnya berbicara tentang keyakinan di tempat kerja. Jangkauan hubungan antara nilai dan etika bisnis barubaru ini lebih diperluas guna memasukkan nilai-nilai spiritual (Kolodinsky, Giacalone, dan Jurkiewicz 2008). Nilai-nilai spiritual tercakup dalam hubungan antara nilai dan etika bisnis, sebab konsep spiritualitas memang telah digambarkan dalam teori perilaku organisasional seperti: nilai, etika, motivasi, kepemimpinan, dan keseimbangan antara hidup dan pekerjaan (Luthans 2009). Kondisi ini menjadi menarik jika dihubungkan dengan pernyataan bahwa tidak hanya fungsi perusahaan yang selama ini jauh dari nilai spiritual, tetapi juga tempat kerja yang selama ini menghalangi berkembangnya dimensi spiritual. Padahal, secara naluriah manusia akan bergerak untuk mencari makna, memuaskan batinnya, dan mencapai nilai-nilai tertentu. Akibat yang terjadi adalah kejenuhan, stres, produktivitas rendah, demotivasi, bahkan puncaknya dapat menyebabkan 
Variabel Anteseden Komitmen Sumber Daya Manusia Sektor Publik Berbasis Spirituality

seseorang mengalami depersonalisasi (Sunarso, Ahsani, dan Indriastuti 2019). Pada dasarnya pencarian makna dan tujuan merupakan hal utama dan hidup dalam harmoni dengan orang lain dipandang sebagai sesuatu yang sangat penting (Ashmos dan Duchon 2000a). Hal-hal inilah yang kemudian akan menjadi dimensi-dimensi spiritualitas.

Penelitian Pawar (2009), Ke et al. (2017) mengungkapkan bahwa spiritualitas organisasi ternyata dapat memberikan pengaruh positif pada pembentukan sikap kerja yang meliputi kepuasan, keterlibatan dan komitmen. Analisis hubungan spiritualitas di tempat kerja dengan berbagai sikap kerja telah banyak diuji, namun peran spritualitas di tempat kerja dan spiritual survival sebagai variable mediasi dalam kaitan spiritual leadership dengan komitmen sumber daya manusia masih belum banyak dilakukan. Studi kali ini dilakukan dengan mengadopsi model yang dikemukakan Fry dan R (2008); Fry, Matherly dan Robert Ouimet (2010) serta mengambil rekomendasi dari temuan (Hakim dan Azlimin 2015) yang menyarankan untuk memasukkan variable individual spirituality sebagai variable dependen. Dalam model yang ditawarkan ini juga memasukkan model Pawar (2009) yang menggambarkan efek langsung dari individual spirituality terhadap sikap kerja (termasuk komitmen kerja). Dalam modelnya Fry, Matherly dan Robert Ouimet (2010) memulai dengan individual spirituality sebagai sebagai anteseden spiritual leadership. Model yang dihipotesiskan diaplikasikan pada negara yang sudah sangat maju pamahaman tingkat spiritualnya dan pada perusahaan yang sudah sering kali mendapatkan penghargaan kelas dunia. Nampaknya model seperti ini nampaknya belum siap diaplikasikan di negara-negara timur yang memiliki budaya menteladani atasan sehingga model yang ditawarkan dicoba untuk dirubah urutan konstruknya dengan memulainya lewat panutan spiritual leadership untuk membangun individual spirituality melalui workplace spirituality dan spiritual survival dalam mengembangkan komitmen sumber daya manusia.

Studi ini dilakukan pada perusahaan daerah air minum Kota Denpasar, Kabupaten Badung, Kabupaten Tabanan yang berada di Provinsi Bali. Dipilihnya ketiga daerah ini mengingat adanya kerja sama diantaranya dalam mentuk pemakaian jaringan pipa bersama, sumber air yang saling terkait dalam bentuk perusahaan air minum "Sarbata" dan secara historis perusahaan daerah air minum Kabupaten Badung dan perusahaan air minum diKota Denpasar merupakan satu perusahaan daerah di tahun 1990an. Penelitian ini memiliki beberapa tujuan yaitu; menganalisis pengaruh spiritual leadership terhadap workplace spirituality; menganalisis pengaruh spiritual leadership terhadap spiritual survival; menganalisis pengaruh workplace spirituality terhadap individual spirituality; menganalisis pengaruh spiritual survival terhadap individual spirituality; menganalisis pengaruh individual spirituality terhadap komitmen sumber daya manusia; menganalisis peran workplace spirituality dan individual spirituality sebagai pemediasi pada pengaruh spiritual leadership terhadap komitmen sumber daya manusia dan menganalisis peran spiritual survival dan individual spirituality sebagai pemediasi pada pengaruh spiritual leadership terhadap komitmen sumber daya manusia.

\section{TINJAUAN PUSTAKA}

\section{Komitmen sumber daya manusia}

Komitmen organisasi memiliki tiga dimensi yaitu komitmen afektif, komitmen normatif dan komitmen berkelanjutan. Ketiga dimensi ini dikembangkan dari teori awal yang dikemukakan oleh Mowday, Steers, dan Porters (1982) yang mengungkapkan bahwa komitmen organisasi terdiri dari dua jenis, yaitu komitmen sikap (attitudinal commitment) dan komitmen perilaku (behavioral commitment). Dua jenis awal komitmen organisasi tersebut kemudian berkembang, komitmen sikap dikembangkan menjadi komitmen afektif dan komitmen normatif, sedangkan komitmen perilaku dikembangkan menjadi komitmen berkelanjutan (Allen dan Meyer 1990). Komitmen organisasi menunjuk pada pengidentifikasian tujuan karyawan dengan tujuan organisasi, kemauan mengerahkan segala daya untuk kepentingan organisasi dan keterikatan untuk tetap menjadi bagian dari organisasi serta mempertahankan nilai-nilai munculnya kesamaan nilai dari organisasi tersebut (Utami 2016 ; Gunastri, Handayani, dan Astakoni 2019). Mowday; Steers; Porter (1982 dalam Luthans 2009) mengemukakan bahwa sebagai sikap, komitmen organisasi (organizational commitment) paling sering didefinisikan sebagai: 1)keinginan kuat untuk tetap sebagai anggota organisasi tertentu; 2) 
keinginan untuk berusaha keras sesuai keinginan organisasi; 3)keyakinan tertentu, penerimaan nilai dan tujuan organisasi. Armstrong (2006) mengemukakan bahwa komitmen organisasional merujuk pada kecintaan dan loyalitas. Komitmen organisasional ini berhubungan dengan kesediaan berada di dalam dan menjadi bagian dari perusahaan. Sopiah (2008) menyimpulkan bahwa komitmen organisasional adalah suatu ikatan psikologis karyawan yang ditandai dengan adanya kepercayaan dan penerimaan yang kuat atas tujuan dan nilai-nilai organisasi, kemauan untuk mengusahakan tercapainya kepentingan organisasi, dan adanya keinginan yang kuat untuk mempertahankan kedudukan sebagai anggota organisasi. Mowday (dalam Sopiah, 2008) menyebut komitmen kerja sebagai istilah lain dari komitmen organisasional yang merupakan dimensi perilaku digunakan untuk menilai kecenderungan karyawan untuk bertahan sebagai anggota organisasi. Berdasarkan paparan tersebut dapat ditarik kesimpulan bahwa komitmen kerja atau komitmen organisasional adalah suatu keadaan dimana individu menganut nilai-nilai dan tujuan organisasi serta merasa ikut memiliki organisasi sehingga memutuskan untuk tetap tinggal dalam organisasi.

\section{Spiritual Leadership}

Istilah "spiritual" berasal dari bahasa inggris dengan kata dasar "spirit" yang memiliki makna antara lain jiwa, roh, semangat, hantu, moral dan tujuan atau makna yang hakiki. Sedangkan dalam bahasa arab istilah spiritual terkait dengan yang rohani dan jasmani dari segala sesuatu. Makna inti dari kata spirit adalah spiritual dan spiritualitas yang bermuara kepada kehakikian, keabadian dan ruh. Spiritualitas bukan sesuatu yang asing bagi manusia, karena merupakan inti kemanusiaan itu sendiri. Manusia terdiri dari unsur material dan spiritual atau unsur jasmani dan rohani. Perilaku manusia merupakan produk tarik menarik antara energi spiritual dan material atau rohaniah dan jasmaniah. Dorongan spiritual senantiasa membuat kemungkinan membawa dimensi material kepada dimensi spiritualnya. Kepemimpinan spiritual (spiritual leadership) merupakan kepemimpinan yang membawa dimensi keduniawian kepada dimensi spiritual. Tuhan merupakan pemimpin sejati yang mengilhami, mencerahkan, membersihkan hati nurani dan memenangkan jiwa hambaNya dengan cara yang sangat bijaksana melalui pendekatan etis dan keteladanan (Mukaromah, 2018). Spiritual leadership merupakan salah satu gaya kepemimpinan yang menjadi alternatif pola kepemimpinan klasik. Konsep spiritual leadership dikembangkan oleh Fry et al. (2011) yang menjelaskan bahwa spiritual leadership terdiri dari nilai-nilai, sikap dan perilaku yang diperlukan untuk memotivasi diri sendiri secara intrinsik dan memenuhi kebutuhan mendasar bagi kesejahteraan spiritual melalui keterpanggilan (calling) dan keanggotaan (membership) yang secara positif mempengaruhi kesejahteraan karyawan, keberlanjutan dan tanggung jawab sosial perusahaan serta kinerja. Spiritual leadership memiliki lima aspek yaitu visi, harapan atau kepercayaan, cinta altruistik, keterpanggilan atau makna dan keanggotaan. Kelima aspek tersebut berproses dalam spiritual leadership guna memuaskan kebutuhan spiritual sehingga secara positif akan mempengaruhi individu dan organisasi yang selanjutnya dikenal dengan "The Triple Bottom Line" (Fry \& Cohen, 2009). Penerapan spiritual leadership dalam sebuah organisasi atau perusahaan membutuhkan situasi dan kondisi lingkungan kerja yang mendukung.

\section{Workplace Spirituality}

Spirit juga sering dimaknai sebagai entitas, makhluk atau sesuatu bentuk energi yang hidup dan nyata, meskipun tidak kelihatan di mata biasa dan tidak punya badan fisik seperti manusia, namun spirit itu ada dan hidup (Hasan, 2010). Lebih lanjut bahwa definisi ini melibatkan perasaan didalam diri (inner feeling), terhubung dengan kerja dan koleganya (Gibson, Ivancevich, Donnely, \& Konopaske, 2009). Terdapat berbagai definisi spiritualitas di tempat kerja, seperti pengalaman dan kebermaknaan kerja, komunitas, dan transedence, yang penyebutannya mungkin berbeda dalam berbagai kajian (Pawar, 2013). Spiritualitas di tempat kerja adalah pengakuan bahwa karyawan memiliki kehidupan batin yang memelihara dan dipelihara oleh pekerjaan yang berarti yang mengambil tempatkan dalam konteks masyarakat (Ashmos dan Duchon 2000a). Konsep spiritualitas ditempat kerja (workplace spirituality) mencerminkan ekspresi dan pengalaman spiritualitas pada tempat kerja yang difasilitasi oleh berbagai aspek-aspek organisasi, seperti budaya, suasana organisasi (organizational climate), budaya organisasi, kepemimpinan, dan praktik organisasi. Oleh karena itu, spiritualitas di tempat kerja dapat didefinisikan sebagai kerangka kerja nilai-nilai organisasi, dibuktikan dengan budaya yang terhubung dengan pihak yang lain dengan memberikan perasaan yang lengkap dan nyaman (completeness and joy). Spiritualitas tempat kerja yaitu upaya untuk mencari dan menemukan makna tertinggi kehidupan untuk kehidupan kerja, untuk 
berkomunikasi antara individu dan rekan-rekan mereka serta orang-orang lain yang entah bagaimana berkontribusi terhadap pekerjaan, juga harmoni atau kesatuan antara individu percaya dengan nilai organisasi mereka. Kinjerski dan Skrypnek (2004) spiritualitas tempat kerja adalah pengalaman yang berbeda dicirikan oleh fitur kognitif, dimensi interpersonal, kehadiran spiritual, dan komponen mistis.

\section{Spiritual Survival}

Daya tahan spiritual (spiritual survival) memiliki dua dimensi yakni Meaning/Calling dan Membership. Panggilan (calling) dimana anggota organisasi merasakan panggilan dalam diri mereka bahwa hidup mereka memiliki makna tertinggi dan bisa membuat perbedaan yang berarti dalam lingkungan organisasi. Keanggotaan (membership) berarti dalam organisasi terbentuk budaya pada cinta sesama yaitu saat pimpinan dan bawahan saling peduli, saling perhatian, dan menghargai diri sendiri dan orang lain sehingga mereka mampu merasakan menjadi bagian dari organisasi tempat bekerja dan secara bersama saling memahami, menghormati satu sama lain (Fry, 2003)

\section{Individual Spirituality}

Semua orang adalah makhluk spiritual (Neil, 1997) dan ketika diintegrasikan dengan kehidupan kerja, spiritualitas menawarkan satu harapan untuk membuat perbedaan bukan hanya sekedar hidup. Ada keinginan untuk mencari pemenuhan, mengintegrasikan spiritualitas dengan pekerjaan (Fry, 2003). Mendefinisikan spiritualitas pada dasarnya sulit karena konstruksinya multidimensi (Klenke, n.d.). Individual spirituality adalah hubungan atau pengalaman pribadi dengan Tuhan atau Yang Ilahi yang menginformasikan keberadaan seseorang dan membentuk makna, tujuan, dan misi mereka dalam kehidupan sehari-hari. Itu tidak perlu mencakup agama juga tidak secara alami mengecualikan agama (Hodge 2001; Karakas 2010).

\section{Spiritual Leadership dan Workplace Spirituality}

Spritualitas merupakan salah satu factor yang bisa dijadikan penentu kinerja organisasi (Utami dan Astakoni 2020). Workplace spirituality dibutuhkan karena dapat berdampak pada individu, lingkungan, maupun organisasi (Ke et al., 2017). Workplace spirituality berarti memandang tempat kerja sebagai tempat yang dihuni oleh orang-orang yang memiliki pikiran (intelek) dan roh, dan percaya bahwa perkembangan roh sama pentingnya dengan mengembangkan pikiran (Ashmos dan Duchon 2000a). Workplace sprituality melibatkan upaya untuk menemukan tujuan utama seseorang dalam kehidupan, untuk mengembangkan hubungan yang kuat dengan rekan kerja dan orang lain yang terkait dengan pekerjaan, dan untuk memiliki konsistensi (atau keselarasan) antara keyakinan inti seseorang dan nilai-nilai organisasi mereka (Milliman et a 1.2003 ). Workplace spirituality adalah salah satu jenis iklim psikologis di mana orang-orang (para pekerja) melihat dirinya memiliki kehidupan internal yang diperlakukan dengan pekerjaan yang bermakna dan ditempatkan dalam konteks komunitas (Duchon dan Plowman 2005). Hasil penelitian yang dilakukan oleh E.Sanders, E.Hopkins, dan Geroy (2004), Helmy (2016) menemukan bahwa spiritual leadership berpengaruh signifikan positif terhadap workplace spirituality. Berdasarkan konsep dan kajian empiris sebelumnya maka hipotesis pertama yang diusulkan sebagai berikut $\left(\mathrm{H}_{1}\right)$; Spiritual Leadership berpengaruh signifikan positif terhadap workplace spirituality.

\section{Spiritual Leadership dan Spiritual Survival}

Spiritual leadership sebagai kombinasi nilai-nilai, sikap, dan perilaku yang dibutuhkan secara intrinsik untuk memotivasi satu sama lain sehingga mereka memiliki perasaan akan daya tahan spiritual ( spiritual survival) melalui calling (panggilan) dan membership (keanggotaan) (Fry, 2003). Menciptakan visi dimana anggota organisasi merasakan ad a panggilan dalam diri mereka bahwa hidup mereka memiliki makna tertinggi dan bisa membuat perbedaan yang berarti didalamnya. Melalui membership terbentuk budaya organisasi/sosial berdasar pada cinta sesama, yaitu saat pemimpin dan bawahan saling peduli, perhatian, dan menghargai diri sendiri dan orang lain, sehingga mereka mampu menghasilkan rasa menjadi bagian dari organisasi secara bersama-sama dan saling memahami serta menghormati satu sama lain. Berdasarkan konsep sebelumnya maka hipotesis kedua yang diusulkan sebagai berikut $\left(\mathrm{H}_{2}\right)$; Spiritual Leadership berpengaruh signifikan positif terhadap spiritual survival.

\section{Workplace Spirituality dan Individual Spirituality}


Spiritualitas adalah suatu keadaan atau pengalaman yang dapat memberikan arah atau makna bagi individu atau memberikan perasaan memahami, semangat, keutuhan dalam diri atau perasaan terhubung. Spiritualitas adalah sebuah proses dalam kehidupan individu, berupa makna dan tujuan. Sehingga semuanya berdampak pada individu lain dan lingkungannya, termasuk organisasi (King \& Nicol, 1999). Tidak dapat dipungkiri bahwa spiritualitas di tempat kerja yang tinggi akan membangun insan-insan yang berbudaya dengan spirit yang tinggi. Spiritualitas dapat membantu individu untuk memperluas batas kesadarannya melampaui batas normal, yang mengarah pada peningkatan intuisi dan kreativitas. Karena dorongan spiritual mengarah pada wawasan yang lebih baik dan juga pertumbuhan dan perkembangan mental yang lebih baik dan dengan demikian peningkatan pribadi secara keseluruhan, kemampuan pemecahan masalah meningkat (Krishnakumar dan Neck 2002). Berdasarkan konsep sebelumnya maka hipotesis ketiga yang diusulkan sebagai berikut $\left(\mathrm{H}_{3}\right)$; workplace spirituality berpengaruh signifikan positif terhadap individual spirituality

\section{Spiritual Survival dan Individual Spirituality}

Spiritual survival yang dimaknai merasakan panggilan dalam diri mereka bahwa hidup mereka memiliki makna tertinggi dan bisa membuat perbedaan yang berarti dalam lingkungan organisasi. Juga dalam organisasi terbentuk budaya cinta sesama sehingga mereka mampu merasakan menjadi bagian dari organisasi tempat bekerja. spiritualitas sebagai "mengekspresikan keinginan kita untuk menemukan makna dan tujuan dalam hidup kita dan merupakan proses mengatur menghidupi seseorang dari nilai-nilai pribadi yang dipegang teguh". Individual spirituality adalah perasaan dasar menjadi terhubung dengan diri seseorang, orang lain, dan seluruh alam semesta (Milliman et al., 2003). Jadi adanya keterpanggilan dan budaya cinta sesama akan membangun individual spirituality secara berkelanjutan. Berdasarkan konsep sebelumnya maka hipotesis keempat yang diusulkan sebagai berikut $\left(\mathrm{H}_{4}\right)$; Spiritual survival berpengaruh signifikan positif terhadap individual spirituality

\section{Individual spirituality dan komitmen sumber daya manusia}

Spritual leadership sebagai iklim organisasi untuk mendukung kapabilitas individu dimana sumber daya individu berupa individual sprituality yang menjadi factor intervening untuk mempengaruhi kemampuan individu melalui spirit at work (Indrajaya, Yeung, Daryanto, \& Sjahrifa, 2019). Meminjam model yang dihipotesiskan oleh (Pawar, 2009) bahwa individual spirituality mempengaruhi kepuasan kerja, keterlibatan kerja dan komitmen organisasional secara langsung. Hal ini berarti secara konsep ada keterkaitan langsung antara individual spirituality dengan komitmen sumber daya manusia perusahaan. Walaupun hasil studi ini memberikan dukungan yang cukup besar untuk hipotesis hubungan antara aspek workplace spirituality dan sikap kerja tetapi tidak untuk hipotesis hubungan antara individual spirituality dan sikap kerja, sehingga hasil studi ini perlu diekpslorasi lebih lanjut. Walaupun hasil temuan (Pawar, 2009) menjelaskan bahwa individual spirituality tidak memiliki pengaruh yang signifikan terhadap sikap kerja. Berdasarkan konsep dan kajian empiris sebelumnya maka hipotesis kelima yang diusulkan sebagai berikut $\left(\mathrm{H}_{5}\right)$; individual spirituality berpengaruh signifikan positif terhadap komitmen sumber daya manusia.

\section{Spiritual leadership, workplace spirituality, individual spirituality dan komitmen sumber daya manusia}

Berbagai model mediasi bisa dikembangkan dalam kaitannya dengan spiritualitas. Meminjam model yang dikembangkan oleh (Fry et al., 2010) bahwa level level spiritual mencakup tiga level dimana salah satunya ada pada level individu. Kemudian model riset yang dikembangkan oleh (Utami et al. 2021) memberikan gambaran bahwa workplace spirituality mampu membangun mediasi antara spiritual leadership dengan individual spirituality. Berdasarkan konsep dan kajian empiris sebelumnya maka hipotesis keenam yang diusulkan sebagai berikut $\left(\mathrm{H}_{6}\right)$ : workplace spirituality dan individual spirituality mampu memediasi secara signifikan hubungan antara spiritual leadership dengan komitmen sumber daya manusia.

\section{Spiritual leadership, spiritual survival, individual spirituality dan komitmen sumber daya manusia}

Fry, Vitucci, dan Cedillo (2005) mengembangkan model spiritual survival dengan dimensi calling dan membership yang sering disebut "The Leadership Quarterly" dimana spiritual survival merupakan variable mediasi dari konstruk leader value dengan outcame. Karyawan memiliki kehidupan batin yang dipelihara dan dipupuk oleh pekerjaan bermakna yang berlangsung dalam 
konteks komunitas. Definisi tersebut, yang didasarkan pada tiga kebutuhan spiritual yang mendasar, berimplikasi pada bagaimana pemimpin dapat meningkatkan kinerja individu, kinerja unit kerja dan kinerja organisasi dengan memelihara semangat dalam bekerja (Duchon dan Plowman 2005). Berdasarkan konsep sebelumnya maka hipotesis ketujuh yang diusulkan sebagai berikut $\left(\mathrm{H}_{7}\right)$ : spiritual survival dan individual spirituality mampu memediasi secara signifikan hubungan antara spiritual leadership dengan komitmen sumber daya manusia.

Berdasarkan paparan konsep dan beberapa kajian empiris yang berhasil diangkat, maka model kerangka berpikir penelitian yang diusulkan sebagai berikut:

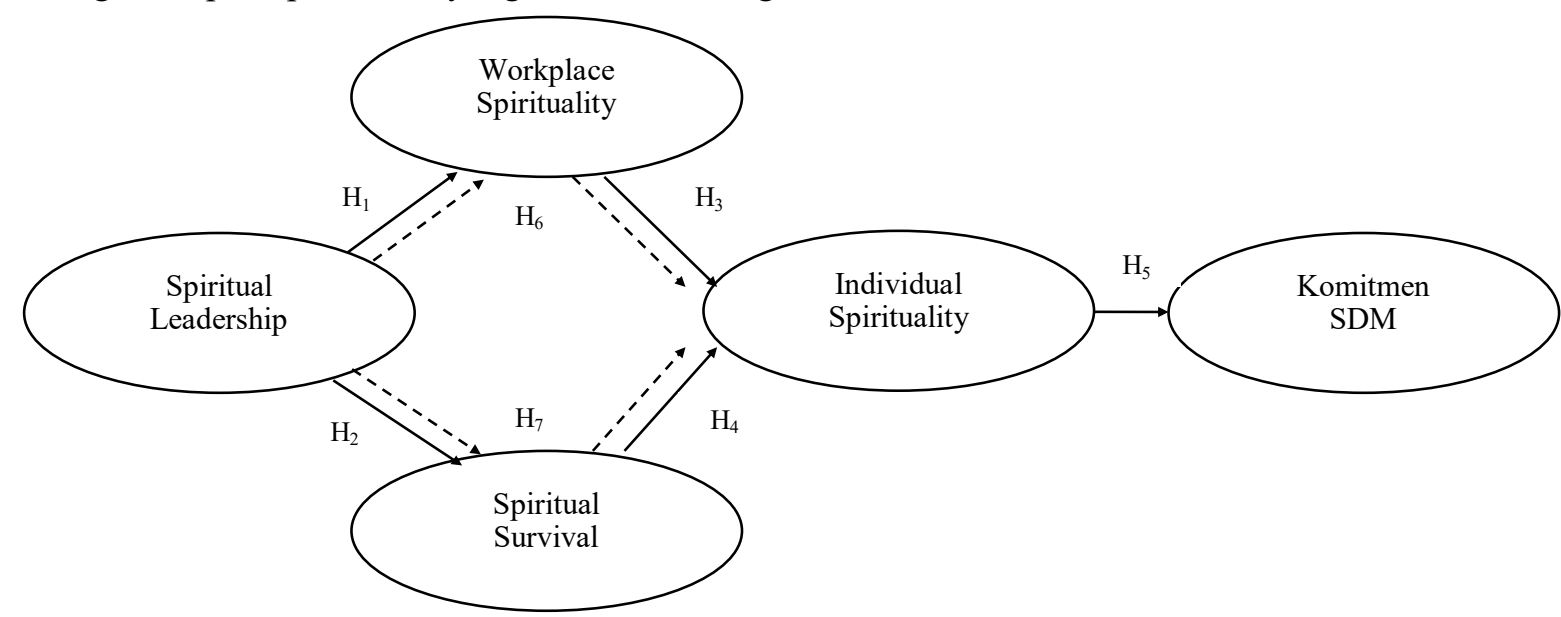

Gambar 1

Model Kerangka Pemikiran Penelitian

\section{METODE}

\section{Populasi dan Sampel}

Seluruh karyawan Perusahaan Daerah Air Minum Kota Denpasar, Kabupaten Badung, Kabupaten Tabanan merupakan populasi penelitian. Jumlah karyawan masing-masing perusahaan daerah tahun 2019 dapat dilihat pada table berikut;

\section{Tabel 1}

Jumlah Karyawan Masing-masing Perusahaan Daerah Air Minum

\begin{tabular}{cc}
\hline Nama Perusahaan & Jumlah Karyawan(orang) \\
\hline PAM Kota Denpasar & 319 \\
PDAM Tirta Mangutama Kabupaten Badung & 336 \\
PDAM Kabupaten Tabanan & 247 \\
Total & 902 \\
\hline
\end{tabular}

Sumber : PDAM/PAM masing-masing Kabupaten/Kota tahun 2020

Sample disesuaikan dengan proporsi jumlah karyawan tiap perusahaan yang kriterianya telah ditetapkan sebelumnya seperti karyawan yang bekerja minimal 5 tahun dan merupakan karyawan tetap perusahaan serta bersedia untuk mengisi kuisioner dan diwawancarai. Berdasarkan ketentuan yang telah ditetapkan maka diambil sejumlah 200 orang karyawan sebagai sampel penelitian berdasarkan pada proporsi masing-masing perusahaan sehingga didapat sampel PAM Kota Denpasar 55 orang responden, PDAM Kabupaten Badung sebanyak 74 orang responden, di PDAM Kabupaten Tabanan sebanyak 71 orang responden.

\section{Definisi Operasional dan Indikator Variabel}

Variabel penelitian adalah hal-hal yang dapat membedakan atau membawa variasi pada nilai. Penelitian ini menggunakan dua variabel yaitu variabel eksogen dan variabel endogen. Variabel 
terikat (Endogeneus Variable) merupakan variabel yang menjadi pusat perhatian peneliti. Dalam penelitian ini yang menjadi variabel endogen adalah komitmen sumber daya manusia $\left(\mathrm{Y}_{3}\right)$, workplace spirituality $\left(\mathrm{Y}_{1}\right)$, spiritual survival $\left(\mathrm{Y}_{2}\right)$, individual spirituality $(\mathrm{M})$. Sedangkan yang menjadi variabel eksogen adalah: spiritual leadership $\left(\mathrm{X}_{1}\right)$. Definisi variable indikator serta skala yang digunakan disajikan lewat tabel 2 berikut:

Tabel 2

Definisi variable, indikator serta skala pengukuran

\begin{tabular}{|c|c|c|c|}
\hline $\begin{array}{l}\text { Konstruk } \\
\text { (Variabel) }\end{array}$ & Definisi Operasional & Dimensi dan Jumlah Indikator & Skala \\
\hline $\begin{array}{c}\text { Spiritual } \\
\text { leadership }(S L)\end{array}$ & $\begin{array}{l}\text { Proses kepemimpinan yang } \\
\text { mengandung nilai-nilai dan sikap } \\
\text { serta tindakan untuk meningkatkan } \\
\text { semangat dan motivasi bawahan }\end{array}$ & $\begin{array}{l}\text { Visi dengan } 3 \text { item indicator, } \\
\text { Hope/harapan dengan } 6 \text { item } \\
\text { indicator dan Altruistic love } \\
\text { dengan } 6 \text { item indicator (Fry } \\
2003 \text {;Pradnyana, Astakoni, dan } \\
\text { Utami 2020), }\end{array}$ & $\begin{array}{l}\text { Skala } \\
\text { Semantic } \\
(1-7)\end{array}$ \\
\hline $\begin{array}{l}\text { Workplace } \\
\text { Spirituality } \\
\quad(W P S)\end{array}$ & $\begin{array}{l}\text { Suatu pengalaman yang memiliki } \\
\text { nilai-nilai, kemampuan, tujuan dan } \\
\text { makna dalam suatu komunitas }\end{array}$ & $\begin{array}{l}\text { Inner life dengan } 5 \text { item indikator, } \\
\text { Meaningfull work dengan dengan } \\
6 \text { item indikator, Bellonging in the } \\
\text { community dengan } 3 \text { item } \\
\text { indikator (Ashmos dan Duchon } \\
2000 \text { b; Utami et al. 2021) }\end{array}$ & $\begin{array}{l}\text { Skala } \\
\text { Semantic } \\
(1-7)\end{array}$ \\
\hline $\begin{array}{c}\text { Spiritual } \\
\text { survival }(S S)\end{array}$ & $\begin{array}{l}\text { Adanya keterpanggilan bahwa } \\
\text { kehidupan seseorang memiliki } \\
\text { makna dan membuat perbedaan } \\
\text { serta dimengerti dan dihargai }\end{array}$ & $\begin{array}{l}\text { Calling (keterpanggilan dengan } 2 \\
\text { item indicator; Membership } \\
\text { dengan } 2 \text { item indicator (Fry, } \\
\text { 2003) }\end{array}$ & $\begin{array}{l}\text { Skala } \\
\text { Semantic } \\
(1-7)\end{array}$ \\
\hline $\begin{array}{c}\text { Individual } \\
\text { spirituality (IS) }\end{array}$ & $\begin{array}{l}\text { Suatu pengalaman yang dimiliki } \\
\text { setiap individu yang mengandung } \\
\text { nilai-nilai untuk menemukan } \\
\text { makna dan tujuan dalam hidup }\end{array}$ & $\begin{array}{l}\text { Individual spirituality diukur } \\
\text { dengan } 9 \text { item indicator (Delaney, } \\
\text { 2005) }\end{array}$ & $\begin{array}{l}\text { Skala } \\
\text { Semantic } \\
(1-7)\end{array}$ \\
\hline $\begin{array}{l}\text { Komitmen } \\
\text { sumber daya } \\
\text { manusia } \\
(\text { KSDM) }\end{array}$ & $\begin{array}{l}\text { Kepercayaan dan loyalitas } \\
\text { karyawan terhadap organisasi yang } \\
\text { didalamnya mengandung nilai- } \\
\text { nilai dan tujuan yang hendak } \\
\text { dicapai }\end{array}$ & $\begin{array}{l}\text { Komitmen afektif sumber daya } \\
\text { manusia didekati dengan } 8 \text { item } \\
\text { indicator (Allen dan Meyer } 1990 \text {; } \\
\text { Utami et al. 2020) }\end{array}$ & $\begin{array}{l}\text { Skala } \\
\text { Semantic } \\
(1-7)\end{array}$ \\
\hline
\end{tabular}

\section{Metode Pengumpulan Data}

Penelitian ini menggunakan teknik pengumpulan data melalui instrument kuesioner, yaitu dengan menggunakan beberapa pertanyaan tertutup yang diberikan kepada karyawan perusahaan mengenai spiritual leadership (kepemimpinan spiritual), workplace spirituality (spiritual di tempat kerja), survival spirituality (ketangguhan spiritual), individual spirituality (spiritual individu) dan komitmen sumber daya manusia.

\section{Teknik Analisis Data}

\section{Analisis Statistik Deskriptif}

Analisis deskriptif dipergunakan untuk menggambarkan/medeskripsikan karakteristik responden dan karakteristik jawaban responden terhadap indikator-indikator yang diangkat dari konstruk penelitian. Dalam studi ini pengolahan datanya menggunakan bantuan program SPSS ver 22.

\section{Analisis Statistik Inferensial}

- $\quad$ Outler Model (Measurement Model) 
Evaluasi model pengukuran (measurement model/outer model), untuk mengukur validitas dan reliabilitas indikator-indikator adalah convergent validity, discriminant validity, composite reliabilitya dan cronbach alpha. Convergent validity merupakan suatu kriteria dalam pengukuran validitas indikator yang bersifat refleksif. Suatu indikator dikatakan valid, jika outer loading $>0,50$ (Ghozali \& Latan, 2012), Discriminant Validity, suatu variabel dikatakan valid, jika akar $A V E$ ( $\sqrt{ } A V E$ atau Square root Average Variance Extracted) lebih besar dari nilai korelasi antar variabel dalam model penelitian (Ghozali \& Latan, 2012), dan AVE lebih besar dari 0,50.Composite reliability dan Cronbach alpha suatu pengukuran dapat dikatakan reliabel, apabila composite reliability dan cronbach alpha memiliki nilai lebih besar dari 0,70.

Inner Model (Structural Model)

Dalam evaluasi model struktural ini akan dilakukan melalui beberapa pendekatan diantaranya: a) $R$-Square (R2), b) Q-Square Predictive Relevance (Q2), dan c) Goodness of Fit $(G o F)$. Melalui $R$-Square(R2) menunjukkan kuat lemahnya suatu model penelitian. Menurut Chin dalam (Latan dan Ghozali 2012), nilai $R$-Square (R2) sebesar 0,67 tergolong model kuat, $R$-Square $(R 2)$ sebesar 0,33 model moderat, dan $R$-Square (R2) sebesar 0,19 tergolong model yang lemah. $Q$ Square Predictive Relevance (Q2) adalah merupakan pengukur seberapa baik observasi yang dilakukan memberikan hasil terhadap model penelitian. Nilai Q-Square Predictive Relevance (Q2) berkisar antara 0 (nol) sampai dengan 1(satu). Kriteria kuat lemahnya model diukur berdasarkan $Q$ Square Predictive Relevance (Q2) menurut (Ghozali, 2013) adalah sebagai berikut: 0,35 (model kuat), 0,15 (model moderat), dan 0,02 (model lemah). Nilai pengukuran berdasarkan Goodness of Fit (GoF) memiliki rentang nilai antara 0 (nol) sampai dengan 1(satu). Kriteria kuat lemahnya model berdasarkan pengukuran Goodness of Fit (GoF) menurut (Ghozali dan Latan 2012), adalah sebagai berikut: 0,36 (GoF large), 0,25 (GoF medium), dan 0,10 (GoF small) (Ferdinand 2014;304)

\section{HASIL DAN PEMBAHASAN}

\section{Deskripsi Karateristik Responden}

Penjabaran karakteristik responden dapat dijelaskan dari aspek jenis kelamin, pendidikan terakhir dan lama bekerja pada perusahaan masing-masing.

\section{Tabel 3}

Deskripsi Karakteristik Responden Penelitian Berdasarkan Jenis Kelamin, Masa Kerja \& Pendidikan Terakhir

\begin{tabular}{|c|c|c|c|c|c|c|}
\hline \multirow{2}{*}{$\begin{array}{c}\text { Jenis } \\
\text { Kelamin }\end{array}$} & \multirow{2}{*}{$\begin{array}{l}\text { Lama Kerja } \\
\text { (tahun) }\end{array}$} & \multirow[b]{2}{*}{ SMA/SMK } & \multicolumn{3}{|c|}{ Pendidikan Terakhir (dalam \%) } & \multirow{2}{*}{$\begin{array}{c}\text { Total } \\
(\text { orang })(\%)\end{array}$} \\
\hline & & & Diploma & Sarjana & PascaSarjana & \\
\hline \multirow{8}{*}{ Laki } & $5-10$ & 0 & 12 & 43 & 0 & 55 \\
\hline & $11-15$ & 2 & 6 & 24 & 1 & 33 \\
\hline & $16-20$ & 0 & 2 & 6 & 3 & 11 \\
\hline & $21-25$ & 0 & 0 & 2 & 1 & 3 \\
\hline & $26-30$ & 1 & 0 & 3 & 0 & 4 \\
\hline & $>30$ & 2 & 0 & 1 & 1 & 4 \\
\hline & Total Laki & 5 & 20 & 79 & 6 & 110 \\
\hline & (Persentase total) & $(4,50)$ & $(18,20)$ & $(71,80)$ & $(5,50)$ & $(100,00)$ \\
\hline \multirow{8}{*}{ Perempuan } & $5-10$ & 0 & 8 & 24 & 0 & 32 \\
\hline & $11-15$ & 0 & 7 & 30 & 4 & 41 \\
\hline & $16-20$ & 3 & 2 & 7 & 0 & 12 \\
\hline & $21-25$ & 1 & 0 & 2 & 0 & 3 \\
\hline & $26-30$ & 0 & 1 & 0 & 0 & 1 \\
\hline & $>30$ & 0 & 0 & 0 & 1 & 1 \\
\hline & TotalPerempuan & 4 & 18 & 63 & 5 & 90 \\
\hline & (Persentase) & $(4,40)$ & $(20,00)$ & $(70,00)$ & $(5,60)$ & $(100,00)$ \\
\hline \multirow{8}{*}{ Total } & $5-10$ & 0 & 20 & 67 & 0 & 87 \\
\hline & $11-15$ & 2 & 13 & 54 & 5 & 74 \\
\hline & $16-20$ & 3 & 4 & 13 & 3 & 23 \\
\hline & $21-25$ & 1 & 0 & 4 & 1 & 6 \\
\hline & $26-30$ & 1 & 1 & 3 & 0 & 5 \\
\hline & $>30$ & 2 & 0 & 1 & 2 & 5 \\
\hline & Total & 9 & 38 & 142 & 11 & 200 \\
\hline & (Persentase) & $(4,50)$ & $(19,00)$ & $(71,00)$ & $(5,50)$ & $(100,00)$ \\
\hline
\end{tabular}


Bila diamati pada Tabel 3, bisa dijabarkan bahwa reponden laki-laki tingkat pendidikannya paling rendah SMA/SMK (4,50\%) dan mayoritas berpendidikan sarjana (S1) sebesar 71,80\%. Untuk responden perempuan kondisinya hampir sama dengan responden laki-laki pendidikannya paling rendah SMA/SMK (4,40\%) dan mayoritas berpendidikan sarjana (S1) sebesar 70,00\%. Secara keseluruhan dilihat dari masa kerja baik gender laki-laki maupun perempuan mayoritas berada pada posisi 5-10 tahun dan 11-5 tahun. Jadi responden yang diangkat dengan pendidikan mayoritas lulusan PT (Sarjana/S1) dan dengan sisa masa kerja yang masih relatif lama, sehingga pihak lembaga/organisasi saat ini memiliki SDM yang masih sangat potensial untuk dikembangkan.

\section{Hasil Statistik Inferensial}

\section{Evaluasi Outer Model}

Dalam mengevaluasi indikator-indikator variabel laten dari kelima variabel yang diangkat dalam studi ini, telah didapat hasil yang memenuhi ketentuan yang ada sebagai berikut Gambar 2 dan tabel $4-7$ :

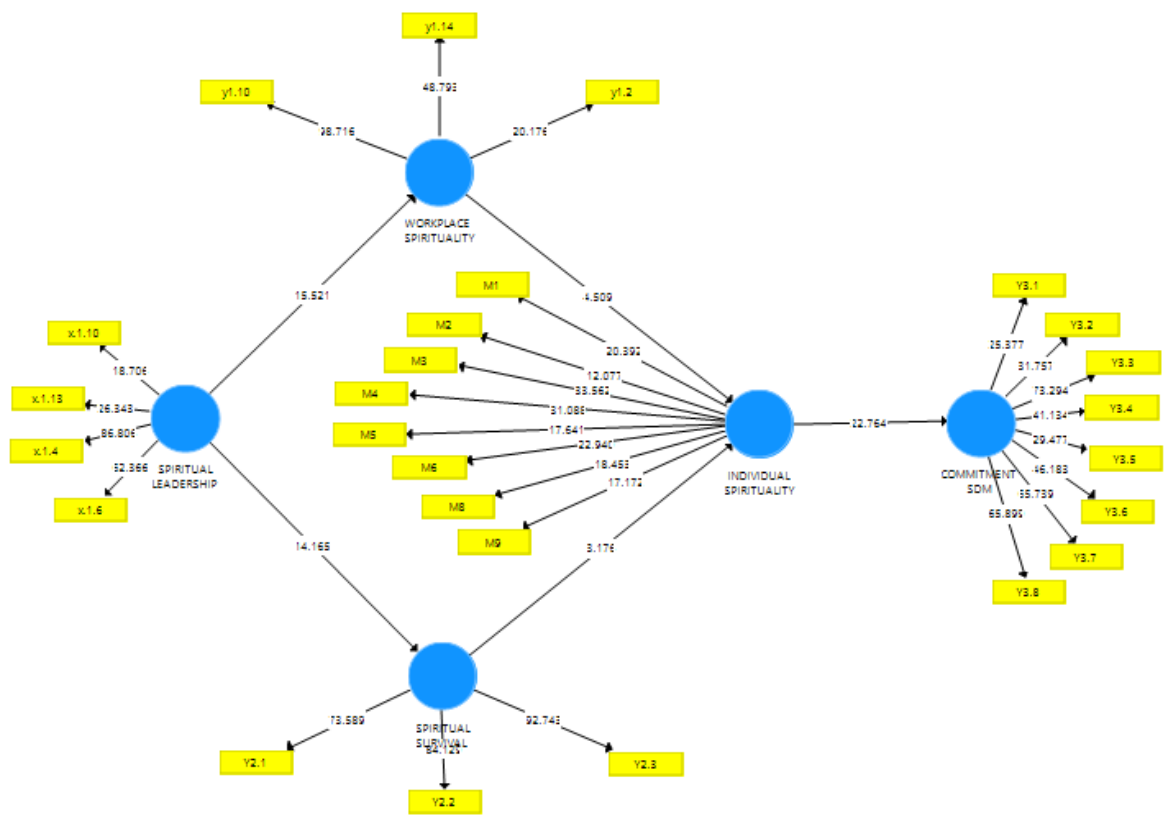

Gambar 2

Uji model pengukuran

Berdasarkan ketentuan convergent validity dari measurement model dengan indikator reflektif dapat dilihat dari outler loading minimal 0,636 (diatas $>0,50$ ) dan nilai AVE minimal 0,600 (atau AVE $>0,50$ ) Hasil perhitungan (Tabel 4) menunjukkan bahwa ouler loading semua indikator dari variable laten berada diatas 0,50 dan nilai nilai average variance extracted (AVE) (Tabel 5) diatas 0,5 , sehingga syarat keduanya sudah terpenuhi sebagai indikator pengukur kontruk laten. 
Wacana Ekonomi (Jurnal Ekonomi Bisnis dan Akuntansi), 20 (1) 2021, 65

Variabel Anteseden Komitmen Sumber Daya Manusia Sektor Publik Berbasis Spirituality

Tabel 4

Outer Loading Hasil Estimasi Model Pengukuran

\begin{tabular}{|c|c|c|c|c|c|}
\hline Indikator Variabel & $\begin{array}{c}\text { Komitmen Sumber } \\
\text { Daya manusia } \\
\text { (KSDM) }\end{array}$ & $\begin{array}{l}\text { Individual } \\
\text { spirituality } \\
\text { (IS) } \\
\end{array}$ & $\begin{array}{c}\text { Spiritual } \\
\text { leadership (SL) }\end{array}$ & $\begin{array}{c}\text { Spiritual } \\
\text { Survival (SS) }\end{array}$ & $\begin{array}{c}\text { Workplace } \\
\text { spirituality (WPS) }\end{array}$ \\
\hline \multicolumn{6}{|l|}{ M1 } \\
\hline \multicolumn{6}{|l|}{ M2 } \\
\hline \multicolumn{6}{|l|}{ M3 } \\
\hline \multicolumn{6}{|l|}{ M4 } \\
\hline \multicolumn{6}{|l|}{ M5 } \\
\hline \multicolumn{6}{|l|}{ M6 } \\
\hline \multicolumn{6}{|l|}{ M8 } \\
\hline \multicolumn{6}{|l|}{ M9 } \\
\hline \multicolumn{6}{|l|}{ Y2.1 } \\
\hline \multicolumn{6}{|l|}{$\mathrm{Y} 2.2$} \\
\hline \multicolumn{6}{|c|}{$\begin{array}{l}0, / 32 \\
0,832\end{array}$} \\
\hline \multicolumn{6}{|c|}{$\begin{array}{l}0,832 \\
0860\end{array}$} \\
\hline \multicolumn{6}{|c|}{$\begin{array}{l}0,860 \\
0.885\end{array}$} \\
\hline \multicolumn{6}{|c|}{$\begin{array}{l}0,885 \\
0,750\end{array}$} \\
\hline \multicolumn{6}{|c|}{$\begin{array}{l}0, / 50 \\
0,792\end{array}$} \\
\hline \multicolumn{6}{|c|}{$\begin{array}{l}0,792 \\
0782\end{array}$} \\
\hline Y3.6 & $\begin{array}{l}0,885 \\
0.935\end{array}$ & \multicolumn{4}{|c|}{0,950} \\
\hline \multicolumn{6}{|c|}{0,938} \\
\hline \multicolumn{6}{|c|}{0,951} \\
\hline \multicolumn{6}{|l|}{$\mathrm{X} 1.10$} \\
\hline \multicolumn{6}{|l|}{$\mathrm{X} 1.13$} \\
\hline \multicolumn{6}{|c|}{0,930} \\
\hline $\mathrm{X} 1.6$ & & & 0,906 & & \\
\hline \multicolumn{6}{|l|}{ Y1.10 } \\
\hline Y1.14 & & & & & 0,924 \\
\hline $\begin{array}{l}\text { Y1.14 } \\
\text { Y1.2 }\end{array}$ & & & & & $\begin{array}{l}0,898 \\
0,821\end{array}$ \\
\hline
\end{tabular}

Suatu pengukuran dapat dikatakan reliabel, apabila composite reliability dan cronbach alpha memiliki nilai lebih besar dari 0,70. Composite reliability adalah merupakan suatu pengukuran reliabilitas antar blok indikator dalam model penelitian.Hasil perhitungan tabel 5 menunjukkan bahwa nilai composite reliability seluruh konstruk telah menunjukkan nilai minimal $0,900(>0.70)$ sehingga memenuhi syarat reliable berdasarkan criteria composite reliability dan nilai cronbach alpha yang dihasilkan lebih besar 0,70 .

Tabel 5

Cronbach's Alpha, Composite Reliability dan Average Variance Extracted (AVE)

\begin{tabular}{cccc}
\hline Konstruk & Cronbach's & Composite & AVE \\
& Reliability & 0,967 & 0,787 \\
Komitmen Sumber Daya manusia (KSDM) & 0,961 & 0,936 & 0,648 \\
Individual spirituality (IS) & 0,924 & 0,900 & 0,694 \\
Spiritual leadership (SL) & 0,885 & 0,962 & 0,895 \\
Spiritual Survival (SS) & 0,942 & 0,913 & 0,778 \\
\hline
\end{tabular}

Pengukuran validitas indikator-indikator yang membentuk variabel laten, dapat pula dilakukan melalui discriminant validity. Output discriminant validity ditunjukkan lewat HTMT (HeterotraitMonotrait Ratio $<0,90$ ) sehingga dinyatakan valid. Output discriminant validity ditunjukkan lewat hasil pengolahan didapat untuk semua kontruk laten dibawah 0,90 , sehingga memenuhi syarat discriminant validity. 
Wacana Ekonomi (Jurnal Ekonomi Bisnis dan Akuntansi), 20 (1) 2021, 66

Variabel Anteseden Komitmen Sumber Daya Manusia Sektor Publik Berbasis Spirituality

Tabel 6

Discriminant Validity (HTMT) hasil estimasi pengukuran

\begin{tabular}{cccccc}
\hline Konstruk & $\begin{array}{c}\text { Komitmen } \\
\text { Sumber Daya } \\
\text { manusia } \\
\text { (KSDM) }\end{array}$ & $\begin{array}{c}\text { Individual } \\
\text { spirituality } \\
\text { (IS) }\end{array}$ & $\begin{array}{c}\text { Spiritual } \\
\text { leadership } \\
\text { (SL) }\end{array}$ & $\begin{array}{c}\text { Spiritual } \\
\text { Survival } \\
\text { (SS) }\end{array}$ & $\begin{array}{c}\text { Workplace } \\
\text { spirituality } \\
\text { (WPS) }\end{array}$ \\
\hline Komitmen Sumber Daya manusia & & & & & \\
(KSDM) & 0,702 & & & & \\
Individual spirituality (IS) & 0,782 & 0,865 & & & \\
Spiritual leadership (SL) & 0,753 & 0,725 & 0,704 & & \\
Spiritual Survival (SS) & 0,846 & 0,767 & 0,736 & 0,840 & - \\
Workplace spirituality (WPS) &
\end{tabular}

\section{Evaluasi Inner Model}

Uji Inner Model dipergunakan untuk mengevaluasi model secara keseluruhan dengan alat analisis dilihat dari sisi R-Square $\left(\mathrm{R}^{2}\right), Q$-Square Predictive Relevance $\left(\mathrm{Q}^{2}\right)$ dan Goodness of Fit (GoF).

Tabel 7

Koefisien Determinasi $\left(\mathrm{R}^{2}\right)$

\begin{tabular}{cccc}
\hline Konstruk & $\begin{array}{c}\text { R Square } \\
\text { Adjusted) }\end{array}$ & $\begin{array}{c}\text { Q-Square Predictive } \\
\text { Relevance }\left(\mathrm{Q}^{2}\right)\end{array}$ & $\begin{array}{c}\text { Goodness of } \\
\text { Fit (GoF) }\end{array}$ \\
\hline Komitmen Sumber Daya manusia (KSDM) & 0,526 & 0,430 & 0,645 \\
Individual spirituality (IS) & 0,553 & 0,326 & 0,599 \\
Spiritual Survival (SS) & 0,445 & 0,398 & 0,556 \\
0,639 \\
\hline
\end{tabular}

Berdasarkan tabel 7, koefisien determinasi (R2) masing masing variable berada pada nilai cukup baik. Kemudian nilai Q-Square Predictive Relevance (Q2) secara keseluruhan didapat diatas 0,30 (kuat). Sedangkan Goodness of Fit (GoF) dari kontruk secara keseluruhan termasuk besar (GoF large). Jadi secara keseluruhan dengan alat analisis dilihat dari sisi R-Square (R2), Q-Square Predictive Relevance (Q2) dan Goodness of Fit $(\mathrm{GoF})$ maka model yang ditawarkan secara keseluruhan dinyatakan baik.

Pengujian hubungan antar konstruk laten seperti yang telah dihipotesiskan dalam penelitian ini dilakukan melalui proses resampling dengan metode bootstraffing. Gambar 3 dan tabel 8 juga tabel 9 memberikan output estimasi untuk pengujian model struktural dimana hasil yang diharapkan adalah Ho ditolak atau nilai sig $<0,05$ (atau nilai $t$ statistic $>1,96$ untuk uji dengan level of signifikan 0,05 .

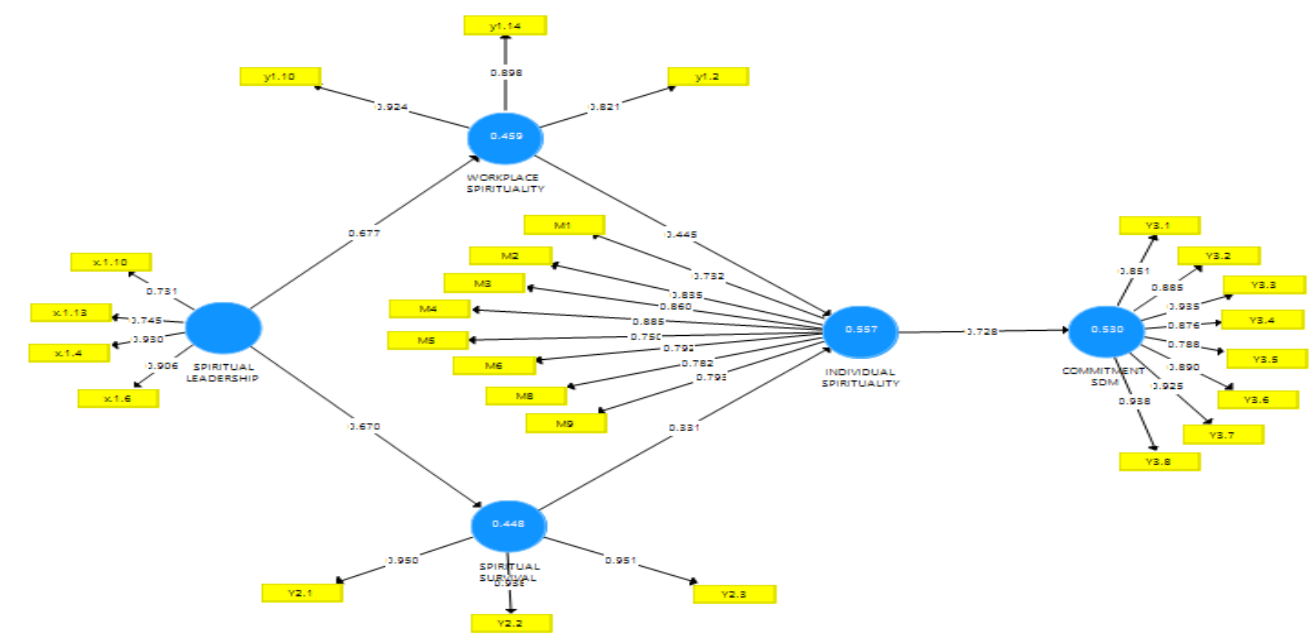

Gambar 3

Hasil uji hipotesis melalui bootstraffing 
Wacana Ekonomi (Jurnal Ekonomi Bisnis dan Akuntansi), 20 (1) 2021, 67

Variabel Anteseden Komitmen Sumber Daya Manusia Sektor Publik Berbasis Spirituality

\begin{tabular}{|c|c|c|c|c|c|c|c|}
\hline \multicolumn{8}{|c|}{$\begin{array}{c}\text { Tabel } 8 \\
\text { Uji Hipotesis }\end{array}$} \\
\hline $\begin{array}{l}\text { Hubungan } \\
\text { Antar } \\
\text { Konstruk }\end{array}$ & $\begin{array}{l}\text { Original } \\
\text { Sample } \\
(\mathrm{O})\end{array}$ & $\begin{array}{c}\text { Sample } \\
\text { Mean (M) }\end{array}$ & $\begin{array}{l}\text { Standard } \\
\text { Error } \\
\text { (STERR) }\end{array}$ & $\begin{array}{l}\text { T Statistics } \\
(\mathrm{O} / \mathrm{STERR})\end{array}$ & P-Value) & \multicolumn{2}{|c|}{ Ket } \\
\hline IS $®$ KSDM & 0,728 & 0,731 & 0,032 & 22,764 & 0,000 & \multicolumn{2}{|c|}{ Signifikan } \\
\hline 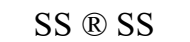 & 0,670 & 0,668 & 0,047 & 14,165 & 0,000 & \multicolumn{2}{|c|}{ Signifikan } \\
\hline SL $®$ WPS & 0,677 & 0,678 & 0,044 & 15,521 & 0,000 & \multicolumn{2}{|c|}{ Signifikan } \\
\hline $\mathrm{SS} \circledast \mathrm{IS}$ & 0,331 & 0,342 & 0,104 & 3,176 & 0,002 & \multicolumn{2}{|c|}{ Signifikan } \\
\hline WPS $®$ IS & 0,445 & 0,436 & 0,099 & 4,509 & 0,000 & \multicolumn{2}{|c|}{ Signifikan } \\
\hline \multicolumn{8}{|c|}{$\begin{array}{c}\text { Tabel } 9 \\
\text { Uji Mediasi }\end{array}$} \\
\hline \multicolumn{2}{|c|}{ Hubungan Antar Konstruk } & $\begin{array}{c}\text { Original } \\
\text { Sample } \\
(\mathrm{O})\end{array}$ & $\begin{array}{r}\text { Sampl } \\
\text { Mean (N }\end{array}$ & $\begin{array}{l}\text { Standard } \\
\text { Error } \\
\text { (STERR) } \\
\end{array}$ & $\begin{array}{c}\text { T Statistics } \\
\text { (O/ } \\
\text { STERR) } \\
\end{array}$ & \multicolumn{2}{|l|}{ P-Value) } \\
\hline \multirow{2}{*}{\multicolumn{2}{|c|}{$\begin{array}{l}\mathrm{SSL} \rightarrow \mathrm{SS} \rightarrow \mathrm{IS} \rightarrow \mathrm{KSDM} \\
\mathrm{SL} \rightarrow \mathrm{WPS} \rightarrow \mathrm{IS} \rightarrow \mathrm{KSDM}\end{array}$}} & 0,161 & 0,169 & 0,059 & 2,758 & 0,006 & Signifikan \\
\hline & & 0,219 & 0,217 & 0,057 & 3,853 & 0,000 & Signifikan \\
\hline
\end{tabular}

\section{Pembahasan}

Tabel 8 dan tabel 9 menunjukan hasil perhitungan yang didapat baik adanya keterkaitan variable secara langsung maupun model mediasi yang dimodelkan sesuai gambar 1 .

Spiritual Leadership dan workplace spirituality

Hipotesis 1, Spiritual leadership berpengaruh signifikan positif terhadap workplace spirituality. Dalam pengujian diperoleh bahwa spiritual leadership berpengaruh positif dengan nilai 0,677 (positif) serta p-value 0,000 (atau t-statistik 15,521>1,96), berarti hipotesis $1\left(\mathrm{H}_{1}\right)$ dapat diterima, sehingga hal ini berarti semakin baik spiritual leadership di perusahaan daerah air minum maka akan semakin baik pula workplace spirituality pada perusahaan tersebut. Hasil penelitian ini sejalan dengan yang dilakukan oleh E.Sanders, E.Hopkins, dan Geroy (2004),Helmy (2016). Pradnyana, Astakoni, dan Utami (2020) yang menemukan bahwa spiritual leadership berpengaruh signifikan positif terhadap workplace spirituality

\section{Spiritual Leadership dan spiritual survival}

Hipotesis 2, Spiritual leadership berpengaruh signifikan positif terhadap spiritual survival. Dalam pengujian diperoleh bahwa spiritual leadership berpengaruh positif dengan nilai 0,670 (positif) serta p-value 0,000 (atau t-statistik 14,165>1,96), berarti hipotesis $2\left(\mathrm{H}_{2}\right)$ dapat diterima, sehingga hal ini berarti semakin baik spiritual leadership di perusahaan daerah air minum maka akan semakin baik pula spiritual survival pada perusahaan tersebut. Hasil penelitian ini sejalan dengan yang dilakukan oleh (Hakim \& Azlimin, 2015) yang menemukan bahwa spiritual leadership berpengaruh signifikan positif terhadap spiritual survival. Hal ini sejalan dengan konsep Fry (2003) bahwa melalui spiritual leadership sebagai kombinasi nilai-nilai, sikap, dan perilaku yang dibutuhkan secara intrinsik untuk memotivasi satu sama lain sehingga karyawan perusahaan memiliki perasaan akan daya tahan spiritual (spiritual survival) melalui rasa keterpanggilan dan keanggotaan.

Workplace spirituality dan individual spirituality

Hipotesis 3, Workplace spirituality berpengaruh signifikan positif terhadap individual spirituality. Dalam pengujian diperoleh bahwa workplace spirituality berpengaruh positif dengan nilai 0,445 (positif) serta $p$-value 0,000 (atau t-statistik 4,509>1,96), berarti hipotesis $3\left(\mathrm{H}_{3}\right)$ dapat diterima, sehingga hal ini berarti semakin baik workplace spirituality pada perusahaan daerah air minum maka akan semakin baik pula individual spirituality pada perusahaan tersebut. Hasil penelitian ini sejalan paparan Krishnakumar dan Neck (2002) bahwa spiritualitas dapat membantu individu untuk memperluas batas kesadarannya melampaui batas normal, yang mengarah pada peningkatan intuisi dan kreativitas. Melalui dorongan spiritual mengarah pada wawasan yang lebih baik dan juga pertumbuhan dan perkembangan mental yang lebih baik dan dengan demikian peningkatan pribadi secara keseluruhan, kemampuan pemecahan masalah meningkat. 


\section{Spiritual survival dan individual spirituality}

Hipotesis 4, spiritual survival berpengaruh signifikan positif terhadap individual spirituality. Dalam pengujian diperoleh bahwa spiritual survival berpengaruh positif dengan nilai 0,331 (positif) serta p-value 0,002 (atau t-statistik 3,176>1,96), berarti hipotesis $4\left(\mathrm{H}_{4}\right)$ dapat diterima, sehingga hal ini berarti semakin baik spiritual survival karyawan pada perusahaan daerah air minum maka akan semakin baik pula individual spirituality pada perusahaan tersebut. Hasil penelitian ini sejalan dengan yang dikemukakan (Milliman et al., 2003). Spiritual survival yang dimaknai merasakan panggilan dalam diri mereka bahwa hidup mereka memiliki makna tertinggi dan bisa membuat perbedaan yang berarti dalam lingkungan organisasi sehingga menjadi terhubung dengan diri seseorang, orang lain, dan seluruh alam semesta.

\section{Individual spirituality dan komitmen sumber daya manusia}

Hipotesis 5, Individual spirituality berpengaruh signifikan positif terhadap komitmen sumber daya manusia. Dalam pengujian diperoleh bahwa individual spirituality berpengaruh positif dengan nilai 0,728 (positif) serta p-value 0,000 (atau t-statistik 22,764>1,96), berarti hipotesis $5\left(\mathrm{H}_{5}\right)$ dapat diterima, sehingga hal ini berarti semakin baik individual spirituality pada perusahaan daerah air minum maka akan semakin meningkat pula komitmen karyawan pada perusahaan tersebut. Hasil penelitian ini sesuai konsep yang dikemukakan Pawar (2009) melalui model yang dihipotesiskan bahwa individual spirituality mempengaruhi kepuasan kerja, keterlibatan kerja dan komitmen organisasional secara langsung. Hal ini berarti secara konsep ada keterkaitan langsung antara individual spirituality karyawan dengan komitmen sumber daya manusia pada perusahaan daerah air minum.

Spiritual Leadership, workplace spirituality, individual spirituality dan komitmen sumber daya manusia

Hipotesis 6, workplace spirituality dan individual spirituality mampu memediasi hubungan spiritual leadership dengan komitmen sumber daya manusia perusahaan. Dalam pengujian diperoleh koefisien positif dengan nilai 0,219 (positif) serta p-value 0,000 (atau t-statistik 3,853>1,96), berarti hipotesis $6\left(\mathrm{H}_{6}\right)$ dapat diterima, sehingga hal ini berarti variable workplace spirituality dan individual spirituality mampu menjadi variable pemediasi spiritual leadership dengan komitmen sumber daya manusia perusahaan daerah air minum.

\section{Spiritual leadership, spiritual survival, individual spirituality dan komitmen sumber daya manusia}

Hipotesis 7, spiritual survival dan individual spirituality mampu memediasi hubungan spiritual leadership dengan komitmen sumber daya manusia perusahaan. Dalam pengujian diperoleh koefisien positif dengan nilai 0,161 (positif) serta p-value 0,006 (atau t-statistik 2,758>1,96), berarti hipotesis 7 $\left(\mathrm{H}_{7}\right)$ dapat diterima, sehingga hal ini berarti variable spiritual survival dan individual spirituality mampu menjadi variable pemediasi spiritual leadership dengan komitmen sumber daya manusia perusahaan daerah air minum.

\section{SIMPULAN}

Hasil penelitian menunjukkan bahwa evaluasi model secara keseluruhan dilihat dari sisi RSquare $\left(\mathrm{R}^{2}\right)$, Q-Square Predictive Relevance $\left(\mathrm{Q}^{2}\right)$ dan Goodness of Fit (GoF) maka model dinyatakan baik. Dalam pengujian hipotesis 1 diperoleh bahwa spiritual leadership berpengaruh signifikan positif terhadap workplace spirituality berarti hipotesis $1\left(\mathrm{H}_{1}\right)$ dapat diterima. Dalam pengujian hipotesis 2 diperoleh bahwa spiritual leadership berpengaruh signifikan positif terhadap spiritual survival berarti hipotesis $2\left(\mathrm{H}_{2}\right)$ dapat diterima. Dalam pengujian hipotesis 3 diperoleh bahwa workplace spirituality berpengaruh signifikan positif terhadap individual spirituality berarti hipotesis $3\left(\mathrm{H}_{3}\right)$ dapat diterima. Dalam pengujian hipotesis 4 diperoleh bahwa spiritual survival berpengaruh signifikan positif terhadap individual spirituality berarti hipotesis $4\left(\mathrm{H}_{4}\right)$ dapat diterima. Dalam pengujian hipotesis 5 diperoleh bahwa individual spirituality berpengaruh signifikan positif terhadap komitmen sumber daya manusia, berarti hipotesis $5\left(\mathrm{H}_{5}\right)$ dapat diterima. Dalam pengujian hipotesis 6 variable workplace spirituality dan individual spirituality mampu menjadi variable pemediasi spiritual leadership dengan komitmen sumber daya manusia. Dalam pengujian hipotesis 7 variable spiritual survival dan individual spirituality mampu menjadi variable pemediasi spiritual 
leadership dengan komitmen sumber daya manusia

Berdasarkan pembahasan hasil penelitian yang telah dilakukan, peneliti dapat memberikan beberapa saran sebagai berikut Secara umum, perusahaan daerah air minum sebaiknya mulai menerapkan secara perlahan model-model kepemimpinan yang berbasis spiritual karena dapat meningkatkan komitmen sumberdaya manusia (karyawan) khususnya dalam hal rasa bangga karyawan menjadi bagian dari perusahaan, dengan mengenalkan model-model pendekatan spiritual individu, kelompok dan organisasi. Untuk penelitian berikutnya disarankan bisa menggunakan variable lain seperti variable moderasi maupun menambah variable endogen selain komitmen, karena penelitian ini hanya menggunakan lima kontruk.

\section{DAFTAR PUSTAKA}

Allen, N. J., \& Meyer, J. P. (1990). The measurement and antecedents of affective, continuance and normative commitment to the organization. Journal of Occupational Psychology, 63(1), 1-18. https:// doi.org/10.1111/j.2044-8325.1990.tb00506.x

Armstrong, M. (2006). A Handbook Of Human Resources Management Practice (Edisi Kese). London: Cambridge University Press.

Ashmos, D. P., \& Duchon, D. (2000). Spirituality at work: A conceptualization and measure. Journal of Management Inquiry, 9(2), 134-144. https://doi.org/10.1177/105649260092008

Delaney, C. (2005). The Spirituality Scale:Development and Psychometric Testing of a Holistic Instrument to Assess the Human Spiritual Dimension. Journal of Holistic Nursing, 23(2), 145-167. https:// doi.org/10.1177/0898010105276180

Duchon, D., \& Plowman, D. A. (2005). Nurturing the spirit at work: Impact on work unit performance. Leadership Quarterly, 16(5), 807-833. https://doi.org/10.1016/j.leaqua.2005.07.008

E.Sanders, J., E.Hopkins, W., \& Geroy, G. D. (2004). Spirituality-Leadership-Commitment Relationships in the Workplace: an Exploratory Assessment. Academy of Management Proceedings, 2004(1), A1A6. https://doi.org/10.5465/ambpp.2004.13862519

Ferdinand, A. (2014). Structural Equation Modeling Dalam Penelitian Manajemen Aplikasi Model-Model Rumit Dalam Penelitian Untuk Skripsi,Tesis dan Desertasi Doktor (5th ed.). Semarang: BP Undip Press.

Fry, L. W. (2003). Toward a theory of spiritual leadership. Leadership Quarterly, 14(6), 693-727. https:// doi.org/10.1016/j.leaqua.2003.09.001

Fry, L. W., \& Cohen, M. P. (2009). Spiritual leadership as a paradigm for organizational transformation and recovery from extended work hours cultures. Journal of Business Ethics, 84(SUPPL. 2), 265-278. https://doi.org/10.1007/s10551-008-9695-2

Fry, L. W., Hannah, S. T., Noel, M., \& Walumbwa, F. O. (2011). Impact of spiritual leadership on unit performance. Leadership Quarterly, 22(2), 259-270. https://doi.org/10.1016/j.leaqua.2011.02.002

Fry, L. W., \& JR, J. W. S. (2008). Maximizing the Triple Bottom Line through Spiritual Leadership. Organizational Dynamics, 37(1), 86-96. https://doi.org/10.1016/j.orgdyn.2007.11.004

Fry, L. W., Latham, J. R., Clinebell, S. K., \& Krahnke, K. (2017). Spiritual leadership as a model for performance excellence: a study of Baldrige award recipients. Journal of Management, Spirituality and Religion, 14(1), 22-47. https://doi.org/10.1080/14766086.2016.1202130

Fry, L. W., Matherly, L. L., \& Robert Ouimet, J. (2010). The Spiritual Leadership Balanced Scorecard Business Model: The case of the Cordon BleuTomasso Corporation. Journal of Management, Spirituality and Religion, 7(4), 283-314. https://doi.org/10.1080/14766086.2010.524983

Fry, L. W., Vitucci, S., \& Cedillo, M. (2005). Spiritual leadership and army transformation: Theory, measurement, and establishing a baseline. Leadership Quarterly, 16(5), 835-862. https:// 
Wacana Ekonomi (Jurnal Ekonomi Bisnis dan Akuntansi), 20 (1) 2021, 70

Variabel Anteseden Komitmen Sumber Daya Manusia Sektor Publik Berbasis Spirituality

doi.org/10.1016/j.leaqua.2005.07.012

Ghozali, I. (2013). Aplikasi Analisis Multivariate dengan Program IBM SPSS 21 Update PLS Regresi. Semarang: Universitas Diponegoro.

Ghozali, I., \& Latan, H. (2012). Partial Least Square, Konsep-Teknik dan Aplikasi Smart PLS 2.0 M3. Semarang: Badan Penerbit Universitas Diponegoro.

Gibson, J. ., Ivancevich, J., Donnely, J. ., \& Konopaske. (2009). Organization Behavior, Structure,Process (13th ed.). New York: Mc Graw-Hill.

Gunastri, N. M., Handayani, A. A. I. R. E., \& Astakoni, I. M. P. (2019). Analisis Penggaruh Kepuasan Kerja Terhadap Organizational Citizenship Behavior (OCB) Dengan Variabel Mediasi Komitmen Organisasional (Studi Pada Koperasi Asadana Semesta Denpasar). E-Jurnal Manajemen Universitas Udayana, 14(3), 82-95. https://doi.org/10.24843/ejmunud.2019.v08.i03.p22

Hakim, A., \& Azlimin. (2015). Model Peningkatan Komitmen Sumber Daya Manusia Berbasis Spiritual Leadership Dan Spiritual Survival Serta Workplace Spirituality Dengan Moderating Individual Spirituality. Unissula, 2(1), 344-356. http://jurnal.unissula.ac.id/index.php/cbam/article/view/318

Hasan. (2010). Spiritualitas Dalam Perilaku Organisasi. Dinamika Ekonomi Dan Bisnis, 7(1), 1-12. https:// doi.org/10.34001/jdeb.v7i1.134

Helmy, I. (2016). Pengaruh Spiritual Leadership dan Emotional Intelligence Terhadap Organizational Citizenship Behaviour dengan Workplace Spirituality Sebagai Variabel Intervening. Jurnal Bisnis Dan Manajemen (JBIMA), 1(1), 72-80. https://journal.peradaban.ac.id/index.php/jbm/article/ view/134

Hodge, D. R. (2001). Spiritual assessment: A review of major qualitative methods and a new framework for assessing spirituality. Social Work, 46(3), 203-214. https://doi.org/10.1093/sw/46.3.203

Indrajaya, A. N., Yeung, S., Daryanto, W. M., \& Sjahrifa, C. (2019). The Conceptual Model of Spiritual Leadership and Spirit at Work as Organizational and Individual Capabilities in Supporting Organizational Commitment and Job Satisfaction. In International Conference on Entrepreneurship and Business Management (ICEBM Untar 2018) (pp. 163-167). https:// doi.org/10.5220/0008489901630167

Karakas, F. (2010). Spirituality and performance in organizations: A literature review. Journal of Business Ethics, 94(1), 89-106. https://doi.org/10.1007/s10551-009-0251-5

Ke, J., Zhang, F., Yan, X., \& Fu, Y. (2017). The Effect of University Teachers' Workplace Spirituality on Employee Engagement: Professional Commitment as Mediator. Creative Education, 08(13), $2147-$ 2154. https://doi.org/10.4236/ce.2017.813145

King, S., \& Nicol, D. M. (1999). Organizational enhancement through recognition of individual spirituality: Reflections of Jaques and Jung. Journal of Organizational Change Management, 12(3), 234-242. https://doi.org/10.1108/09534819910274026

Kinjerski, V. M., \& Skrypnek, B. J. (2004). Defining sprit at work: finding common ground. Journal of Organizational Change Management, 17(1), 26-42. https://doi.org/10.1108/09534810410511288

Klenke, K. (n.d.). The "S" Factor In Leadership Education, Practice, And Research. Journal Of Education Fo Business, 56. https://doi.org/10.1080/08832320309599089

Kolodinsky, R. W., Giacalone, R. A., \& Jurkiewicz, C. L. (2008). Workplace values and outcomes: Exploring personal, organizational, and interactive workplace spirituality. Journal of Business Ethics, 81, 465480. https://doi.org/10.1007/s10551-007-9507-0

Krishnakumar, S., \& Neck, C. P. (2002). The "what", "why" and "how" of spirituality in the workplace. Journal of Managerial Psychology, 17(3), 153-164. https://doi.org/10.1108/02683940210423060

Latan, H., \& Ghozali, I. (2012). Partial Least Squares Konsep Teknik dan Aplikasi SmartPLS 2.0 Untuk 
Luthans, F. (2009a). Organization Behavior. New Jersey: Pearson Education Inc.

Luthans, F. (2009b). Perilaku Organisasi (Edisi Sepu). Yogyakarta: Andi.

Mansor, N., Ismail, A. H., Mohd. Alwi, M. A., \& Anwar, N. (2013). Relationship between spiritual leadership and organizational commitment in Malaysians' oil and Gas industry. Asian Social Science, 9(7), 179 -191. https://doi.org/10.5539/ass.v9n7p179

Milliman, J., J, A., Czaplewski, \& Ferguson, J. (2003). Workplace spirituality and employee work attitudes: An exploratory empirical assessment. Journal of Organizational Change Management, 16(4), 426-447. https://doi.org/10.1108/09534810310484172

Mowday, R. T., Steers, R. M., \& Porters, L. W. (1982). Employee-Organization linka ges : the psychology of commitment, absenteeism and turnover. New York: Academic Press.

Mukaromah, S. M. (2018). Kepemimpinan Spiritual (Spiritual Leadership) Guru Sekolah Dasar Dalam Pembentukan Karakter Peserta Didik. Elementary: Jurnal Ilmiah Pendidikan Dasar, 4(1), 63. https:// doi.org/10.32332/elementary.v4i1.1029

Neil, J. A. (1997). Spirituality In Management Education: A Guide To Resourches. Journal of Management Education, 21(1), 121-139. https://doi.org/10.1177/105256299702100111

Pawar, B. S. (2009). Individual spirituality, workplace spirituality and work attitudes: An empirical test of direct and interaction effects. Leadership and Organization Development Journal, 30(8), 759-777. https://doi.org/10.1108/01437730911003911

Pawar, B. S. (2013). Leadership Spiritual Behaviors Toward Subordinates: An Empirical Examination of the Effects of a Leader's Individual Spirituality and Organizational Spirituality. Journal of Business Ethics, 122, 439-452. https://link.springer.com/article/10.1007/s10551-013-1772-5

Pradnyana, I. G. . O., Astakoni, I. M. P., \& Utami, N. M. S. (2020). Komitmen Sumber Daya Manusia Sektor Publik Berbasis Kepemimpinan Spiritual Melalui Spiritualitas Di Tempat Kerja. Widya Manajemen, 2(2), 27-42. https://doi.org/10.32795/widyamanajemen.v2i2.877

Sopiah. (2008). Prilaku Organisasional (1st ed.). Yogyakarta: PT Andi.

Sunarso1, Ahsani, R. F., \& Indriastuti, D. R. (2019). Pengaruh Spiritual Di Tempat Kerja Pada Perilaku Kewargaan Organisasional Pekerja Sektor Formal Kota Surakarta. Research Fair Unisri, 3(1), 196203. http://dx.doi.org/10.33061/rsfu.v3i1.2580

Utami, N. M. S. (2016). Pengaruh Kepemimpinan, Kompetensi Karyawan,Komitmen Organisasi Terhadap Kinerja Karyawan Asuransi Jiwa Bersama Bumi Putra 1912 Kantor Cabang Ubung Denpasar. In Prosiding Seminar Nasional Hasil Penelitioan (pp. 15-35). Denpasar: Sekolah Tinggi Ilmu Manajemen Handayani Denpasar.

Utami, N. M. S., \& Astakoni, I. M. P. (2020). Peran Gender Sebagai Group Pada Kepemimpinan Path Goal Dan Motivasi Sebagai Determinan Kinerja Guru. Widya Manajemen, 2(1), 36-46. https:// doi.org/10.32795/widyamanajemen.v2i1.548

Utami, N. M. S., Sapta, I. K. S., Astakoni, I. M. P., \& Nursiani, N. P. (2020). Peran Gender Sebagai Variabel Moderasi Pada Model Komitmen Organisasional Organizational Citizenship Behavior Dan Kinerja Karyawan. E-Jurnal Binawakya, 14(12), 3551-3568. https://doi.org/10.33758/mbi.v14i12.598

Utami, N. M. S., Sapta, I. K. S., Verawati, Y., \& Astakoni, I. M. P. (2021). Relationship between Workplace Spirituality, Organizational Commitment and Organizational Citizenship Behavior. Journal of Asian Finance, Economics and Business, 8(1), 507-517. https://doi.org/10.13106/jafeb.2021.vo18.no1.507

Yogatama, L. A. M., \& Widyarini, N. (2015). Kajian Spiritualitas di Tempat Kerja pada Konteks Organisasi Bisnis. Jurnal Psikologi, 42(1), 1-14. https://doi.org/10.22146/jpsi.6939 